\author{
ZBIGNIEW KWIECIŃSKI \\ Uniwersytet Mikołaja Kopernika \\ $w$ Toruniu
}

\title{
AGNOTOLOGIA PEDAGOGICZNA. ZARYS PROBLEMATYKI. TRZY SUBIEKTYWNE OPOWIEŚCI
}

\begin{abstract}
AвSTRact. Kwieciński Zbigniew, Agnotologia pedagogiczna. Zarys problematyki. Trzy subiektywne opowieści [An Outline of Pedagogical Agnotology. Three Subjective Tales]. Studia Edukacyjne nr 46, 2017, Poznań 2017, pp. 23-38. Adam Mickiewicz University Press. ISSN 1233-6688. DOI: 10.14746/ se.2017.46.2
\end{abstract}

The term "agnotology” was introduced by Robert Proctor. Agnotology is the study on the spread of ignorance, its social scope and impact, causes and effects. The author tried to analyze whether it is possible that ignorance is disseminated by schools, the principal institution of the Enlightenment, i.e. not only of equipping invididuals with broad knowledge, but of taking care of each individual's ability to judge (critical thinking). The author discusses three examples of deliberate structural changes to indicate that school "reforms" may bring about effects opposite to the intended ones, have an offside effect of belated imitation and widespread side effects, which destroy the entire education system.

Key words: agnotology, pedagogy of ignorance, risk of error of main reformers of education

\section{Czym zajmuje się agnotologia?}

\section{Agnotologia to neologizm przypisywany Robertowi N. Proctorowi}

oznaczający badania, studia nad tworzeniem i rozpowszechnianiem ignorancji, zamętu informacyjnego, zapominania, półprawd i wątpliwości. Pływając po oceanach ignorancji i niewiedzy możemy napotkać nieskończenie wiele jej przykładów, a przy tym nie każda ignorancja jest $\mathrm{zła}^{1}$.

1 R.N. Proctor, A missing term to describe the cultural production of ignorance (and its study), [w:] Agnotology. The making and unmaking of ignorance, red. R.N. Proctor, L. Schiebinger, Stanford 2008. 
Rdzeń tego pojęcia jest taki, jak w słowie „agnostyk”. Agnotologia - odwrotnie niż epistemologia, która pyta, dlaczego to wiemy - pyta, dlaczego o tym nie wiemy.

Ignorancja, przedmiot badań agnotologii, przejawia się na przykład jako utajanie prawdy, apatia intelektualna, cenzurowanie, dezinformacja, sianie lęku poprzez fałszywą informację, zapominanie, amnezja. Szczególnie ważnym obiektem studiów agnotologicznych jest kulturowo celowo skonstruowana ignorancja, stwarzana przez specjalne grupy interesów, powodująca zamieszanie, tłumienie prawdy w społecznie ważnych kwestiach. Szczególnie skuteczne jest tu zasiewanie ziarna niesprawdzalnych wątpliwości.

Najbardziej staje się to widoczne w trakcie kampanii wyborczych, kiedy rozpowszechniane na wielką skalę są plotki i posądzanie rywali o różne rzekome wykroczenia moralne, przestępstwa korupcyjne, powiązania ze służbami specjalnymi obcych, wrogich państw. Dla takich celów wykorzystywane są kościoły, stronnicze media i skorumpowani dziennikarze oraz eksperci, wyspecjalizowane agencje PR, obiecywanie wyborcom spełnienia ich oczekiwań, przy świadomości ich nierealności, odwoływanie się do powszechnych ukrytych uprzedzeń, stereotypów, takich jak ksenofobie, antysemityzm, antyintelektualizm, zawiść wobec bogatych².

Zatem, ignorancja może być stanem pierwotnym, wrodzoną niewiedzą, wiedzą nigdy nie nabytą, wiedzą niepełną lub wykrzywioną, wiedzą zapomnianą lub wypartą, trwałością wiedzy już dawno nieaktualnej (,skamieliną wiedzy"), selektywnym wyborem informacji i interpretacji, konstruktem biernym lub aktywnym, czy chwytem strategicznym.

\section{Przykłady szerzenia ignorancji}

Klasycznym przykładem szerzenia ignorancji jest reklama przemysłu tytoniowego, zachwalająca zupełną nieszkodliwość zdrowotną palenia papierosów „naszej” marki.

Innym przykładem są „,tajemnice wojskowe”, jak na przykład posądzenie Iraku o rzekome posiadanie broni masowego rażenia, które posłużyło rozpętaniu wojny o nieobliczalnie wielkich szkodach, a której prawdziwą przyczyną były prawdopodobnie interesy materialne lobby amerykańskich miliarderów i militarystów.

Podobne skutki przynoszą: wytwarzanie aury sekretności i ciągłe „zbliżanie się do odsłonięcia straszliwej prawdy", wszelkie poufności, niechęci do innych grup, wstyd, przemilczenia, nieuczestniczenie, udawanie niemożno-

\footnotetext{
2 Agnotology; blog Alexander, „La Cademera”, 2.04.2012.
} 
ści obiecanych i oczekiwanych działań, wspieranie środowiskowych troglodytów (w pobliskim kraju znany prawicowy prostak pokonuje w wyborach powszechnych byłego prezesa akademii nauk), w parlamentach zasiadają ludzie, którzy bardzo skąpo posługują się wiedzą i prawdą.

Nierzadkim dziś przejawem ignorancji jest nieprzyswajanie nowych technologii (np. ruchy przeciwko szczepionkom, przeciwko zapłodnieniom metodą in vitro), czy ignorancja w kwestiach rasowych, kulturowych i seksualnych.

Badaczki feministyczne dowodzą, na przykład, że bardzo wielu mężczyzn (pewnie mniej kobiet) nie wie o istnieniu i funkcjach clitoris, rozpowszechniona jest niewiedza o orgazmie, mężczyźni często traktują kobiety instrumentalnie, jako źródło tylko ich przyjemności, a wiele kobiet udaje orgazm, żeby okazać partnerowi jak „wspaniale się spisał”. Tragikomicznym przejawem ignorancji jest walka z gender jako podstępnym szatanem, prowadzona przez osoby, które nie mają pojęcia, co to słowo znaczy.

Jest też „,święta ignorancja” - nie wiedzieć jak stawiać opór w przyjmowaniu prawdy, uznawać pewne kłamstwa jako moralnie uzasadnione. Do tego rodzaju ignorancji (,skamielin wiedzy") należy szerzenie i podtrzymywanie wierzeń oraz dogmatów dawno już odrzuconych i obalonych przez naukę oraz przez Kościół (po zaaprobowaniu teorii ewolucji), takich jak "teoria” kreatywności uznająca za Biblią, że Bóg stworzył świat w ciągu sześciu dni (pojęcie owych dni zostało zredefiniowane jako epoki wyłaniania się kolejnych etapów ewolucji Wszechświata, Układu Słonecznego, Ziemi i życia na ziemi, pojawienia się na niej człowieka).

Innym widocznym upowszechnianiem półprawdy na użytek umocowania władzy przez autorytarnych przywódców politycznych jest „ujawnianie" wyzysku poszczególnych członków Unii Europejskich przez... Unię Europejską (Brexit, Orban, PiS), a także podejmowanie ważnych decyzji politycznych po upozorowanych "szerokich konsultacjach", albo w takim pośpiechu legislacyjnym, że parlamentarzyści nieraz głosują nad powierzchownie znanymi przez nich projektami ustaw.

Przykładem pożytecznej ignorancji może być odkrycie „Indii Zachodnich", a w efekcie dwóch wielkich kontynentów. Odkrycie to było skutkiem ignorancji ówczesnej geografii i Krzysztofa Kolumba. Innym takim przykładem są powtarzalne empirycznie ustalenia, że analfabeci są szczęśliwsi niż intelektualiści, którzy często odczuwają swoje życie jako nieustanny ciąg tragicznych wyborów egzystencjalnych, choć co do tego funkcjonuje też inny pogląd.

Szczególnie manipulacje językiem propagandy politycznej i debaty publicznej wyrządzają wielkie szkody w postaci szerzenia nienawiści rasowej, narodowościowej, religijnej i światopoglądowej. Osobliwie było to uwidocz- 
nione w języku propagandy hitlerowskiego nazizmu. Dotyczyła ona - jak opisuje i analizuje to szczegółowo Victor Klemperer w książce LTI. Notatnik filolo$g a$ - nie tylko szeroko upowszechnionego i zaakceptowanego przez Niemców uprzedmiotowienia Żydów jako szkodliwych pasożytów, godnych całkowitego wytępienia, ale też komunikatów z frontu. Kiedy wojska hitlerowskie były w odwrocie komunikowano, że "nasze bohaterskie oddziały walczą o $(. . .)^{\prime \prime 3}$. Jako przykład odwrócenia znaczeń V. Klemperer podaje przymiotnik "fanatyczny". Miało ono i ma sens pejoratywny. W ostatnim roku wojny w lipcu 1944 użyto tego słowa w odwróconym znaczeniu, w znaczeniu pochwalnym "Nasze fanatycznie walczace [w Normandii] oddziały"4. W listopadzie tegoż roku J. Goebbels napisał, że „sytuację może jeszcze uratować wściekty fanatyzm"

Michał Głowiński w kilku książkach zebranych potem w monografii Mowa zła podał dziesiątki przykładów manipulacji językiem publicznym. W okresie wydarzeń marcowych 1968 roku użycie „nowego” języka

ujawniło się w trzech punktach: 1) w reaktywowaniu formuł okresu właściwego stalinizmu, tzn. z pierwszej połowy lat pięćdziesiątych, 2) we wprowadzeniu w życie tradycyjnego języka prawicy, przede wszystkim w jego postaci z lat trzydziestych, 3) w odwoływaniu się do języka prasy brukowej apelującej do najniższych instynktów ${ }^{6}$.

Największymi wrogami naszego narodu stali się „syjoniści”, choć mało kto rozumiał co to słowo znaczy, ale uznano je jako określenie Polaków pochodzenia żydowskiego, z których bardzo wielu wydalono z kraju. „Nie zdziwię się, kiedy przeczytam, że lewica intelektualna jest najgorszą faszystowsko-syjonistyczną prawicą"7. Udział w inwazji wojskowej na Czechosłowację nazwano „bratnią pomocą”. Księży, którzy wbrew zakazowi Episkopatu współpracowali z SB - w zamian za płatne lekcje religii, przywileje socjalne nauczycieli - nazwano „księżmi-patriotami”. „Moralne” było to wszystko, co nie przeszkadzało $\mathrm{w}$ sprawowaniu przez aparat polityczny nieograniczonej władzy.

Współcześnie takie słowa, jak: „postkomuna”, „komuniści i złodzieje”, , "lewactwo" "Targowica" "łże-elity", "gorszy sort”, ,zdradzieckie mordy” (na określenie przeciwników politycznych o poglądach innych niż konserwatywno-narodowe i ksenofobiczne) są w codziennym użytku dyskursu publicznego.

\footnotetext{
${ }^{3}$ V. Klemperer, LTI. Notatnik filologa, Kraków 1983.

${ }^{4}$ Tamże, s. 72.

${ }^{5}$ Tamże.

${ }^{6}$ M. Głowiński, Zła mowa. Jak nie dać się propagandzie, Warszawa 2016, s. 25.

7 Tamże, s. 27.
} 


\section{Szerzenie ignorancji $w$ nauce?}

Fala ignorancji, oszustw i plagiatów naukowych zalewa obecnie również wyższe uczelnie. Jak mantrę powtarzali to na Kongresie Kultury Akademickiej w Krakowie w 2014 roku rektorzy i byli rektorzy największych polskich uniwersytetów oraz wybitni przedstawiciele organizacji naukowych. Skargi na plagiaty i oszustwa należą też do najczęściej napływających w ostatnich latach do Komisji Etyki Polskiej Akademii Nauk. Dotyczy to wszystkich dziedzin i dyscyplin nauki, nie tylko w Polsce. Istnieją już osobne monografie na temat szerzenia ignorancji w poszczególnych dyscyplinach nauki.

Badacze ignorancji twierdzą, że warto wrócić do odrzuconych już koncepcji K. Marksa (że ideologia jest świadomym okłamywaniem dla ochrony interesów), czy teorii psychoanalitycznych (ignorancja ma źródła w podświadomych popędach i pragnieniach).

Podam tego przykłady.

W trakcie Zgromadzenia Ogólnego PAN 7 grudnia 2017 roku próbowano uchwalić „Stanowisko Polskiej Akademii Nauk w sprawie Puszczy Białowieskiej". Wcześniej odbyły się dwie konferencje odpowiedniego komitetu Akademii, w tym jedna z udziałem specjalistów od leśnictwa z Czech, Słowacji, Białorusi i Szwecji, także polskich ministrów. Uczestnicy tych konferencji mieli sprzeczne poglądy na stosowanie wycinki („,ochrony sanitarnej”) Puszczy.

Uczestnikom obrad Zgromadzenia Ogólnego przedstawiono do dyskusji i głosowania taki oto tekst: „Konkluzje konferencji zorganizowanych przez PAN wskazują, że nie ma jednoznacznych przesłanek, wskazujących na nadrzędność ochrony różnorodności biologicznej Puszczy Białowieskiej poprzez stosowanie zabiegów sanitarnych, względem naturalnych procesów lasotwórczych wyzwalanych pojawieniami się kornika drukarza". W długiej, burzliwej dyskusji wypracowano inne brzmienie stanowiska, sprowadzające się do poparcia przez PAN zakazu wycinki Puszczy. Jeden z dyskutantów powiedział: „Nauka znajduje się pomiędzy dwoma potworami: komercjalizacji i ideologizacji". Dyskusja się bardzo wydłużała, argumenty za i przeciw powtarzano. Ujawniono w niej, że przewodniczący komitetu PAN, który tę konferencję zorganizował i podsumował w pierwotnym brzmieniu stanowiska, jest wicedyrektorem Lasów Państwowych (sic!). Ostrzeżono też zebranych, że wezwanie do zaprzestania wycinki (,aktywnej ochrony") Puszczy może zaszkodzić wizerunkowi Akademii w oczach władz. Znaczna część uczestników obrad opuściła salę.

W głosowaniu tajnym za zakazem wycinania Puszczy opowiedziało się niewiele mniej niż 50 osób, a jeszcze mniej przeciw takiemu wezwaniu. Głosowanie uznano za nieważne ze względu na brak quorum. Prowadzący obrady skomentował to tak: „Wrócimy do tego”. Po kilku dniach członkowie PAN 
otrzymali nową wersję "Stanowiska Akademii”. Ktoś uchwalił stanowisko Akademii... bez udziału Akademii. Ktoś miał swoje interesy w zaproponowaniu pierwotnego tekstu „Stanowiska”.

\section{Ignorancja powszechna}

S.M. Anwaruddin twierdzi ${ }^{8}$, że ignorancja występuje na każdym poziomie i rodzaju inteligencji, a dyplomy pełnią rolę zasłon dymnych dla jej powszechności. Co więcej, są autorzy naukowi, którzy dowodzą, jak np. Ken Wilber (patrz także M.B. Kielar) ${ }^{9}$, że ludzkość dokonała obecnie „,autokorekty ewolucyjnej" i cofa się do wcześniejszych etapów rozwoju świadomości, a także, że zapanowało "globalne barbarzyństwo manipulacji”"10.

Jak możliwa jest tak szeroko rozlewająca się ignorancja? Oto szczególny przypadek wykorzystania teorii dla zrozumienia ignorancji. W słynnej, szeroko dyskutowanej książce Prześniona rewolucja Andrzej Leder ${ }^{11}$ posłużył się psychoanalizą Jacques'a Lacana do wyjaśnienia przełomowych wydarzeń w historii najnowszej Polski. Największa klasa w społeczeństwie międzywojennym - klasa chłopska miała dwa, podzielane zbiorowo, wielkie pragnienia: pozbycia się ziemiaństwa, jako posiadaczy należnej chłopom ziemi, oraz pozbycia się Żydów, jako monopolistów handlu na obszarach wiejskich. Te dwa wielkie pragnienia chłopów zostały spełnione przez hitlerowców i komunistów. Chłopi nie dokonali tych rewolucji. Tak oto A. Leder obala wiele schematów wyjaśniania historii najnowszej Polski.

Do podobnego typu argumentacji wyjaśniania... przyszłości Polski sięgnęli autorzy „Raportu Polska 2050”12, opracowanego przez Komitet Prognoz „Polska 2000 Plus” przy Prezydium PAN. Przedstawiono w nim trzy możliwe scenariusze rozwoju naszego kraju do połowy XXI wieku: (1) scenariusz stałego aktywnego wzrostu gospodarczego, kulturalnego, wypracowanie swoistego dla Polski wzoru tego rozwoju, przy pogłębiających się sojuszach międzynarodowych, (2) scenariusz bezwładnego dryfowania, ugrzęźnięcia w tym samym miejscu oraz imitacji Zachodu, oraz (3) scenariusz negatywny - Polski zamkniętej na świat, skłóconej z sąsiadami, z autarkiczną gospodarką, rządzonej autorytarnie, z możliwymi nawrotami neofaszyzmu. Autorzy

\footnotetext{
${ }^{8}$ S.M. Anwaruddin, Pedagogy of ignorance, Educational Philosophy and Theory, 2015, 7(47).

9 K. Wilber, Trump and post-truth. An evolutionary self-correction, Seria "Integral Life", e-book, 2017. OP-Ed (patrz także M.B. Kielar).

${ }^{10}$ T. Bartoś, Cywilizacja manipulacji, Przegląd, 2017, 49.

11 A. Leder, Prześniona rewolucja. Ćwiczenia z logiki historycznej, Warszawa 2013.

12 Raport Polska 2050, red. M. Kleiber i in., 2011.
} 
ostrzegają w swoim Raporcie, że zrealizowanie scenariusza aktywnego rozwoju może napotkać na silne bariery.

Najtrudniejszą do przełamania barierą długookresową są przemiany w systemie kulturowym. (...) Poziom zmian w sferze politycznej, a przede wszystkim mentalnej, jest nadal bardzo niski. Można pokusić się o, być może nieco przesadne, stwierdzenie, że pewne negatywne właściwości (czy cechy) systemu kulturowego zostały w swoisty sposób utwardzone i są mniej podatne na zmiany, niż można było sądzić w początkach transformacji ${ }^{13}$.

Autorzy poszukując możliwie klarownego opisu składników owego systemu kulturowego, piszą, że

stanowi on zbitkę elementów wywodzących się z różnych epok, tradycji historycznych, krótkookresowych wizji związanych z przemianami ustrojowymi, a także z rozczarowań, jakie owe zmiany ze sobą przyniosły (...); można się pokusić o zaprezentowanie pewnej zbitki (zlepki) bardzo różnych jego elementów. Wywodzą się one z cywilizacji agrarnej, mają swoją otoczkę w anarchizującej demokracji szlacheckiej, silnych wpływach tradycjonalistycznego Kościoła katolickiego, w braku zaufania do instytucji państwa, akceptacji egalitaryzmu socjalistycznego, niechęci do innych, w pielęgnowaniu wspomnień, zarówno zwycięstw, jak i klęsk, niedostatecznej umiejętności wspólnego działania oraz w niskim kapitale społecznym ${ }^{14}$.

Niespójność opisywanego w „Raporcie” systemu kulturowego (za C.G. Jungiem można go nazwać zbiorową nieświadomością) wywołuje silne i trudne do pokonania podziały Polaków w sporach o przeszłość, możliwość kompromisów, poziom tolerancji i podejście do obcych, o przywiązania do mitów i w ocenie minionych zdarzeń. A zatem, według tez tego „Raportu Polska 2050” zbiorowa ignorancja jest najsilniejszą barierą rozwoju naszego kraju.

Psychologiczne mechanizmy tych głębokich i niekoniecznie nieusuwalnych podziałów wyjaśniają psychologowie polityki. Szczególnie Janusz Reykowski bardzo dogłębnie objaśnił owo pęknięcie na „dwie Polski”, które opiera się na dominujących przekonaniach: na konserwatywnej, zwróconej ku przeszłości ochronie wspólnoty oraz liberalnym dążeniu do autonomii, do indywidualnej podmiotowości. Te dwie orientacje są jednocześnie głęboko zakorzenione w ludzkiej kondycji, w istocie gatunkowej człowieka, każdej jednostki ludzkiej. Ich zrównoważenie jest warunkiem przetrwania zarówno wspólnoty, jak i podmiotowości, lecz „pomyślności ludzkich społeczeństw może zagrażać dominacja jednej ideologicznej perspektywy"15.

\footnotetext{
13 Tamże, s. 113.

14 Tamże, s. 114.

${ }^{15}$ J. Reykowski, Różnice mentalności jako źródta ideologicznych konfliktów, Nauka, 2013, 3, s. 39.
} 
W podobnym kierunku zmierzają rozważania Stanisława Kowalika. I znowu mamy tu tezę, że o naszych podziałach i losach decyduje zbiorowa nieświadomość i „zacięta walka” pomiędzy jej dwoma rodzajami ${ }^{16}$.

Do trwania i pogłębiania podziałów społecznych przyczyniają się okresy rządów autorytarnych. Ważną i interesującą interpretację cyklicznych nawrotów takich rządów sformułowała wybitna socjolożka brytyjska Margaret Archer $^{17}$. Badając $\mathrm{z}$ makroperspektywy historycznej i socjologicznej wyłanianie się zdecentralizowanych i scentralizowanych systemów oświatowych, ustaliła ona, że systemy zdecentralizowane mają tendencję do stałego rozwoju, natomiast systemy scentralizowane (na przykładzie Rosji i Francji) przechodzą przez cykle wzrostu i nawrotu, ze względu na inne relacje roszczeń pomiędzy władzami a oddolnymi podmiotami społecznymi (tu: nauczyciele i ich związki, rodzice, samorządy, władze lokalne i regionalne, eksperci, media i inne).

Polska należy do państw scentralizowanych, z wyraźną tendencją do owej amplitudy (go - stop) wskazanej przez M. Archer. Tym bardziej trudny do zrealizowania wydaje się postulat J. Reykowskiego zrównoważenia dwóch naszych powszechnych skłonności do konserwatyzmu i liberalizmu.

\section{Od socjopatologii edukacji do agnotologii pedagogicznej. Czyżby znowu pan Jourdain?}

Agnotologia pedagogiczna to studia nad ignorancją w edukacji, przez edukację wytwarzaną celowo, jako efektu ubocznego instytucjonalnej edukacji, jako spontanicznego procesu bez udziału świadomych tego podmiotów, nad zewnętrznymi i utrwalonymi szeroko szkodliwymi edukacyjnie: niewiedzą, głupotą, fałszywymi przekonaniami, w tym mitami dotyczącymi właśnie szkoły jako głównej instytucji powszechnego oświecenia publicznego.

Dotychczas, przez wiele lat zajmowałem się (sam i z zespołami) nierównościami efektów kształcenia szkolnego dzieci i młodzieży, uwarunkowanymi przez różne typy środowisk (wieś, miasto), usytuowania rodziny pochodzenia w strukturze społecznej, ale także bezpośrednimi i dalekosiężnymi skutkami tych nierówności, zarówno w kształtowaniu się ich trajektorii edukacyjnych (selekcji społecznych), jak i wpływu na poziom oraz jakość życia w dorosłości: na rodzaj i charakter pracy, pozycję społeczno-zawodową rodziny, materialny poziom życia, dobór małżeński i jakość życia własnej rodziny, aktywność kulturalną i wartościowość wykorzystania czasu wolnego, na

${ }^{16}$ S. Kowalik, Uśpione człowieczeństwo. Szkice z psychologii globalizacji, Warszawa 2015.

17 M. Archer, Social origins of educational systems, London 1979; patrz szerokie omówienie tego dzieła przez S. Kowalskiego, Systemy oświatowe scentralizowane i zdecentralizowane w świetle wyników badań M. S. Archer, Socjologia Wychowania AUNC, 1984, 5. 
system wyznawanych wartości, orientację polityczną, zaangażowanie obywatelskie i reagowania na zmiany społeczne, na warunki „startu szkolnego” stwarzane własnym dzieciom, nad postrzeganiem roli szkoły podstawowej w ich życiu po upływie wielu lat od jej opuszczenia (po 15, 25, 35, 45 latach).

Pewne wątki z tego pola badawczego podjęli niektórzy moi uczniowie, podnoszący problematykę nierówności na obszarach wiejskich, jak i nierówności w procesach studiów wyższych $(\text { R. Borowicz })^{18}$, nierówności w dostępie kobiet do szkolnictwa w skali świata (A. Gromkowska-Melosik ${ }^{19}$ ), badania ciągłości i luki pokoleniowej (K. Szafraniec i zespół, M. Kwiecińska-Zdrenka, P. Mikiewicz i inni) ${ }^{20}$, czy jakość życia młodzieży pozostającej poza nauką i pracą (J. Kotliński) ${ }^{21}$.

Niemało studiów empirycznych i analitycznych poświęciłem działalności samej szkoły, na przykład badaliśmy intensywność pracy nauczycieli, przemoc strukturalną i symboliczną szkoły, realizację przez szkołę powierzonych jej zadań wychowawczych. Szereg prac empirycznych miało charakter ostrzegawczy, dotyczący możliwych głębokich i szerokich negatywnych skutków nieprzemyślanych reform szkolnych (np. wprowadzenie gminnych szkół zbiorczych, reforma szkolna J. Kuberskiego i J. Wołczyka z lat 1972-1974 naśladujące strukturę szkolnictwa radzieckiego - reformy mające skrywane, ale zamierzone jako celowe obniżanie poziomu umysłowego Polaków).

Tym pracom empirycznym towarzyszyła poszerzająca się świadomość teoretyczna dotycząca zarówno nierówności, jak i selekcji szkolnych, teorie usprawiedliwiające je (teoria merytokracji, szeroko obecna w amerykańskim neoliberalizmie), wyjaśniające (P. Bourdieu i B. Bernstein), czy krytyczno-emancypacyjne, jak też systemowych uwarunkowań degradacji systemu edukacyjnego. Wreszcie dużo uwagi poświęciłem społecznie upowszechnionym mitom dotyczącym społecznej funkcji szkolnictwa.

Czy zatem nie odkryłem, że cały czas uprawiałem agnotologię, tyle że o tym nie wiedziałem, jak pan Jourdain - bohater sztuki „Mieszczanin szlachcicem" Moliera?

Agnotologia to studia nad upowszechnianiem ignorancji i zakresem jej występowania w różnych dziedzinach życia, kultury, aktywności publicznej, przesądów, braków wiedzy o własnej historii, choć także obejmuje swoim

${ }^{18}$ R. Borowicz, Równość i sprawiedliwość. Studium na przykładzie oświaty, Warszawa 1988.

${ }_{19}$ A. Gromkowska-Melosik, Edukacja i problem (nie)równości kobiet. Studium dynamiki dostępu, Kraków 2013.

${ }^{20} \mathrm{~K}$. Szafraniec i zespół, Anomia - przesilenie tożsamości. Jednostka i społeczeństwo wobec zmiany, Torun 1986; M. Kwiecińska-Zdrenka, Aktywni czy bezradni wobec własnej przyszłości, Toruń 2004; P. Mikiewicz, Społeczne światy szkót średnich. Od trajektorii marginesu do trajektorii sukcesu, Wrocław 2005 i inni.

${ }^{21}$ J. Kotliński, Między bylejakościa życia a dobrostanem w narracjach młodzieży, Wrocław 2017 (nieopublikowana rozprawa doktorska). 
zakresem instytucje edukacyjne, naukowe, kształcenie i poziom nauczycieli. Zakres agnotologii jest szerszy niż zakres socjopatologii szkoły, ze szczególnie wyrazistą różnicą - z akcentem na upowszechnianie, jako świadomość aktywną.

Opiszę kilka przykładów świadomego upowszechniania... przez system szkolny, centralnie sterowany i nieustannie „reformowany”.

\section{Efekt odwrócenia}

Na początku przejęcia władzy przez ekipę partyjną Edwarda Gierka powołano w roku 1971 zespół ekspertów do spraw reformy oświaty, pod kierunkiem znanego socjologa profesora Jana Szczepańskiego. Miało to być przejawem nowoczesnego, jak na Zachodzie, projektowania ważnych zmian systemowych, z aktywnym udziałem ekspertów akademickich i wybitnych praktyków. Zespół prof. J. Szczepańskiego przygotował niezwykle szybko kilka scenariuszy reformy systemu oświaty, opublikowany w 1973 roku. Raport obejmował zmiany wszystkich instytucjonalnych i nieinstytucjonalnych składników systemu oświaty od przedszkola do szkół wyższych, instytucje kształcenia równoległego oraz wszystkie elementy społeczeństwa wychowującego.

Propozycje „Raportu” zostały przyjęte przez Sejm przez aklamację 14 października tegoż roku. Tyle tylko, że to co uchwalił wówczas Sejm różniło się zasadniczo od propozycji „Raportu” prof. J. Szczepańskiego, co zrozumiałem już po paru miesiącach, a latem 1975 roku, podczas IV Światowego Kongresu Socjologii Wsi w Toruniu, kiedy to opowiedział mnie i prof. Zbigniewowi T. Wierzbickiemu sam profesor Jan Szczepański.

Wróćmy do początku reformy systemu oświaty. Nie czekając na ustawę Sejmu, do której w ogóle nie doszło, kierownictwo Ministerstwa Oświaty już w roku 1972 - Jerzy Kuberski i Jerzy Wołczyk - rozpoczęli energiczną przebudowę sieci szkolnej, której głównym ogniwem miała być zbiorcza szkoła gminna, gromadząca w klasach starszych uczniów z mniejszych wsi. Dzięki temu dzieci wiejskie miały mieć szanse na zdobywanie wiedzy i umiejętności porównywalnych z miastem. Szkoła gminna miała skupiać komplet nauczycieli-specjalistów przedmiotowych i mieć znacznie lepsze wyposażenie (pracownie, biblioteki, boiska, sale gimnastyczne, baseny).

W naszych raportach w IRWiR PAN dostrzegaliśmy nierealność tego projektu: 1) z powodu braku środków na owo lepsze wyposażanie infrastruktury szkół zbiorczych; na etaty i mieszkania dla masy potrzebnych nauczycieli oraz 2) z powodu braku środków na sprawne dowożenie dzieci do tych szkół (stołówki, drogi, autobusy, kierowcy). Na początku roku szkolnego 1973/1974, 
w zespole - Mikołaj Kozakiewicz, Ryszard Borowicz, Zbigniew Kwieciński, Włodzimierz Wincławski - przeprowadziliśmy pospieszny sondaż nad przyczynami, przebiegiem i skutkami bojkotu reformy szkolnictwa na wsi. Rodzice z małych wsi nie chcieli, by zmuszano ich dzieci do pokonywania pieszo wielu nieraz kilometrów do szkoły. Ich dzieci były skazane na brak czasu na odrabianie zadań domowych i przygotowania się do następnych lekcji. Raport nasz miał klauzę poufności, ale otrzymały go wszelkie władze i... nic $\mathrm{z}$ tego nie wynikło.

Jesienią 1973 roku wiceminister Jerzy Wołczyk odwiedził mnie bez zapowiedzi, w trakcie naszego stałego seminarium czwartkowego w Stacji Naukowo-Badawczej IRWiR PAN w Toruniu i zaproponował, abym ja i zespół ekspertów Ministerstwa włączyli się do opracowania wspólnego (z IBE i resortem) referatu o osiągnięciach polskiej reformy oświaty na wsi na kongresie UNESCO w Nairobi. Oczywiście odmówiłem. Jednakże usłyszałem zaskakujący argument: szkoła zbiorcza oderwie dzieci od zacofanych rodzin chłopskich, co przyspieszy budowę socjalizmu na wsi.

W IRWiR PAN nadal prowadziliśmy badania nad związkami zmian strukturalnych i zmianami w różnicach osiągnięć szkolnych uczniów z małych szkół i szkół zbiorczych. Różnice te nie zmniejszyły się. Zawracaliśmy do punktów wyjścia. Raymond Boudon nazwał to efektem odwrócenia, ja nazywałem to w swoich publikacjach efektem bumerangowym.

\section{Efekt pułapki ofsajdowej}

Kolejnymi filarami reformy J. Kuberskiego i J. Wołczyka były powszechna 10-letnia ogólnokształcąca szkoła średnia oraz reforma studiów wyższych.

Równocześnie ze zmianami sieci szkolnej na obszarach wiejskich ruszyła reforma powszechnego szkolnictwa, która miała wydłużyć powszechną, jednolitą szkołę do 10 lat. Znowu argumentem naszych reformatorów było wzorowanie się na osiągnięciach "towarzyszy radzieckich” i NRD-owskich, które to państwa osiągnęły wyższy poziom „rozwiniętego socjalizmu”. Taka przedłużona szkoła ogólnokształcąca miała być "przepustką" do studiów wyższych lub do szkół zawodowych.

Nie czekając na absolwentów nowej 10-latki, natychmiast wdrożono reformę szkolnictwa wyższego. Większość kierunków studiów - zwłaszcza humanistycznych - skrócono o rok (do czterech lat). Do planów nauczania wprowadzono siedem dyscyplin ideologiczno-politycznych, a w ciągu jednego z lat studiów jeden dzień w tygodniu przeznaczony był na szkolenie wojskowe, obejmujące także kobiety. Na efekty nie trzeba było długo czekać. Na rynek pracy weszło kilkadziesiąt tysięcy absolwentów bez znajomości ka- 
nonu własnej dyscypliny, nie mówiąc już o znajomości najnowszych badań naukowych i metodologii badań we własnej dyscyplinie, co jest szczególnie ważne w przypadku zawodów nauczycielskich.

Powróćmy jednak do radzieckich osiągnięć w upowszechnianiu 10-letniej szkoły oraz jej udziału w niwelowaniu nierówności społecznych. Jesienią 1973 roku wybrałem się - w ramach umowy pomiędzy akademiami nauk na trzymiesięczne studium badawcze do Związku Radzieckiego. Dotarłem do wielu prac odradzającej się tam empirycznej socjologii oświaty. Okazało się, że w wielu ośrodkach tego olbrzymiego państwa realizowano program badań nad aspiracjami i planami młodzieży z różnych środowisk. W świetle badań socjologów moskiewskich, leningradzkich, tallińskich i nowosybirskich (Akademgorodok) zachodzą silne związki korelacyjne pomiędzy poziomem aspiracji młodzieży kończącej szkoły średnie a położeniem materialnym i statusem rodziców (np. Fillipow, Titma, Wasiliewa). Ponadto, niski poziom aspiracji jest skorelowany z przynależnością do mniejszości etnicznych (Arutiunian). A zatem, 10-latka nie spełniła funkcji wyrównawczych.

Największa jednak niespodzianka, wręcz sensacyjne "odkrycie” czekało mnie podczas seminarium w zespole socjologicznym prof. Tatiany Zasławskiej. Było to w styczniu 1974 roku. Jeden z jej młodych współpracowników zapytał mnie: „Zbigniewie, czy możesz nam wyjaśnić, dlaczego polskie władze ogłosiły jesienią ubiegłego roku reformę strukturalną, naśladującą wzory radzieckie, podczas gdy nasze władze partyjne i rządowe w lipcu 1973 roku ogłosiły negatywne skutki reformy z 1958 roku i postanowiły przyjąć strukturę szkolnictwa wzorowaną na Polsce, tj. 7(8) + 4 albo $5(3+2)$ "? Podarował mi egzemplarz ich czołowego dziennika partyjnego z treścią decyzji KC KPZR i rządu (w CK KPSS i Sowietie Ministrow).

Po powrocie usiłowałem zakomunikować to władzom oświatowym, poczynając od dość obleganego odczytu w IBE. Nikt nie przejął się moimi rewelacjami.

Tak zatem twórcy wielkiej polskiej reformy oświaty wpuścili Polaków i ich dzieci w pułapkę ofsajdową, parli do zwycięstwa na polu już spalonym. Polacy zapłacili masową ignorancją.

\section{Wulkaniczne efekty uboczne}

Zaangażowanie centralnych reformatorów szkolnictwa (przypomnijmy: instytucji oświeceniowej) $\mathrm{w}$ krzewieniu powszechnej ignorancji poprzez zmiany struktur oświatowych jest niezmiennie wysokie. W 1999 roku minister profesor Mirosław Handke rozpoczął tworzenie sieci 3-letnich gimnazjów. 
W szerokich konsultacjach (uczestniczyłem w spotkaniu z ministrem, Senatem UAM i na jednym spotkaniu z wielką gromadą ciała doradczego ministra w Ministerstwie) przedstawiał ważkie argumenty:

1) należy wrócić do tradycji przedwojennego gimnazjum, które doskonale sprawdziło się w kształceniu i wychowaniu młodzieży;

2) trzeba dostosować strukturę szkolnictwa polskiego do kształtu zaleconego przez Unię Europejską, by zapewnić młodzieży międzynarodową mobilność po każdym szczeblu kształcenia;

3) gimnazjum powszechne zrówna szanse edukacyjne młodzieży wiejskiej i miejskiej, gdyż cała młodzież przejdzie przez taki sam jednolity system kształcenia.

W dyskusjach przedstawiałem warunki konieczne do powodzenia tej reformy. Skrócenie o dwa lata zbyt długiej i infantylnej szkoły podstawowej jest nadzieją na zbudowanie sieci szkół o wyższych standardach kształcenia, z lepszą kadrą, pracującą refleksyjnie i stosującą aktywne metody nauczania. Jednakże:

1) Jak szybko można zbudować nową sieć takich szkół?

2) Jak pozyskać dla nich odpowiednią kadrę?

3) Jak wyrównać szanse edukacyjne młodzieży z różnych środowisk, które nie zależą od struktury szkolnictwa, lecz od systemu uwarunkowań pozaszkolnych?

4) Jaka jest specyficzna koncepcja programowa i wychowawcza gimnazjów?

5) Czy przedłużenie powszechnej i obowiązkowej szkoły ogólnokształcącej nie zrujnuje sieci szkół zawodowych i nie spowoduje masowego oraz gwałtownego rozrostu sieci liceów, a potem wielkiego „uderzenia” ich absolwentów na studia wyższe?

Reforma ruszyła. Już po roku pewien profesor z zespołem udowodnił, że różnice środowiskowe zniknęły po ukończeniu pierwszej klasy gimnazjów. Zaczęły znikać szybko i to na bardzo dużą skalę szkoły zawodowe, gdyż upadały zakłady pracy z przestarzałymi technologiami, a odbudowa nowoczesnych szerokoprofilowych szkół zawodowych byłaby bardzo kosztowna.

Najkrótszą i najtańszą drogą dla karier młodzieży było ukończenie liceum i podjęcie studiów wyższych. Otworzyły się szerokie wrota dla quasi-rynku edukacyjnego. Jak grzyby po deszczu powstawały niepubliczne szkoły wyższe, oferujące "studia” zawodowe, a potem magisterskie. Także uniwersytety uległy tej presji; zrezygnowały z limitów przyjęć i w większości kierunków przeszły na system: trzyletnie studia zawodowe („,studia licencjackie”) i studia II stopnia (kończone dyplomem magistra). Tylko niektóre, bardzo nieliczne uczelnie niepubliczne prowadziły studia na wysokim poziomie. Tylko niektóre kierunki uniwersyteckie obroniły się przed tym przełamaniem ich 
na dwie połówki, z których druga była i została grą pozorów kadry akademickiej i studentów.

I tak oto romantyczny powrót do dobrej przeszłości skończył się rozpadem systemu szkolnictwa zawodowego i śmiercią studiów akademickich.

Posłużyłem się tylko kilkoma przykładami celowych zmian strukturalnych w oświacie, które sprzyjały upowszechnianiu ignorancji. Dalsze pola studiów agnotologicznych są jeszcze bardzo rozległe. CDN

\section{BIBLIOGRAFIA}

Agnotology; blog Alexander, „La Cademera”, 2.04.2012.

Alcoff L.M., Epistemology of ignorance. Three Types [w:] Race and epistemologies of ignorance, red. S. Shannon, T. Nancy, State University, New York 2007.

Anwaruddin S.M., Pedagogy of ignorance, Educational Philosophy and Theory, 2015, 7(47).

Archacka M., Praktyki wtadzy, oporu i wolności we wspótczesnej szkole polskiej, niepublikowana rozprawa doktorska, DSW, Wrocław 2017.

Archer M., Social origins of educational systems [patrz szerokie omówienie tego dzieła przez S. Kowalskiego], Sage Publications, London 1979.

Arutiunian J.W., Opyt sociołogiczeskogo izuczenja sieła, Izdat. Mosk. Uniwersiteta, Moskwa 1968.

Arutiunian J.W., O razwitii i zbliżeni kultury sowieckich nacji, Socjołogiczeskoje Issledowaniea, 1974, 2.

Bartoś T., Cywilizacja manipulacji, Przegląd, 2017, 49.

Borowicz R., Równość i sprawiedliwość. Studium na przykładzie oświaty, PWN, Warszawa 1988.

Boryczko M., Paradoksalne funkcje szkoły. Studium etnograficzno-krytyczne, Wydawnictwo UG, Gdańsk 2014.

Boudon R., Efekt odwrócenia. Niezamierzone skutki działań społecznych, przekł. A. Karpowicz, Zakład Wydawniczy Nomos, Kraków 2009.

Bourdieu P., Passerom L-B., Reprodukcja. Elementy teorii nauczania, przekł. E. Neu, wstęp i redakcja naukowa A. Kłoskowska, PWN, Warszawa 1990.

[Chomsky N.] Trump's America and the new work order - conversation with Noam Chomsky być. J. Polichroniou, Trutthout, 06.01.2017; OP-ED.

Domalewski J., Mikiewicz P., Młodzież w zreformowanym systemie szkolnym, IRWiR PAN, Torun - Warszawa 2004.

Dudzikowa M., Mit o szkole jako miejscu "wszechstronnego rozwoju” ucznia. Eseje etnopedagogiczne, Oficyna Wydawnicza Impuls, Kraków 2004.

Fillipow F.P., Wsieobszczeje srednie obrazowanie. Socjotogiczeskije problemy, Moskwa 1975 (egzemplarz udostępniony przez autora z wydania w zamkniętym obiegu).

Fillipow F.R., Wsieobszczeuje srednie obrazzowanije w SSS. Soxołogiczeskieje problemy, Izdatielstwo „Mysl”, Moskwa 1976.

Giroux H.A., The Violence of organizing forgetting. Thinking beyond America's imagination, City Lights Books, San Francisco 2014.

Giroux H.A., Witkowski L., Edukacja i sfera publiczna. Idee i doświadczenia pedagogiki radykalnej, Oficyna Wydawnicza Impuls, Kraków 2010.

Głowiński M., Zła mowa. Jak nie dać się propagandzie, Wielka Litera, Warszawa 2016. 
Gromkowska-Melosik A., Edukacja i problem (nie)równości kobiet. Studium dynamiki dostępu, Oficyna Wydawnicza Impuls, Kraków 2013.

Gromkowska-Melosik A., Gmerek T., Problemy nierówności w teorii i praktyce edukacyjnej, Oficyna Wydawnicza Impuls, Kraków 2008.

Gromkowska-Melosik A., Szymański M.J. (red.), Edukacja i nierówność. Trajektorie sukcesu i marginalizacji, Wydawnictwo Naukowe UAM, Poznań 2014.

Harding S.T., Two influential theory of ignorance and philosophy's interest in ignoring them, Hypatia... A Journal of Feminist Pedagogy, 2006 3(21).

Klemperer V., LTI. Notatnik filologa, Wydawnictwo Literackie, Kraków 1983.

Kotliński J., Między bylejakościa życia a dobrostanem w narracjach młodzieży, Wrocław 2017 (nieopublikowana rozprawa doktorska w DSW).

Kowalik S., Uśpione człowieczeństwo. Szkice z psychologii globalizacji, Wydawnictwo Akademickie SEDNO, Warszawa 2015.

Kowalski S., Systemy oświatowe scentralizowane i zdecentralizowane w świetle wyników badań M. S. Archer, Socjologia Wychowania AUNC, 1984, 5.

Kozakiewicz M., Bariery awansu poprzez wykształcenie, IW CRZZ, Warszawa 1973.

Kozakiewicz M., Kwieciński Z., Wincławski W., Raport o dostępie młodzieży do kształcenia na różnych szczeblach szkolnictwa, IRWiR PAN, Warszawa 1973.

Kwaśnica R., Dwie racjonalności. Od filozofii sensu ku pedagogice ogólnej, ODN, Wrocław 1987.

Kwiecińska F.E., Kwieciński Z., Kształcenie a plany życiowe młodzieży. Analiza badań radzieckich, Wydawnictwo Naukowe UMK, Torun 1979.

Kwiecińska-Zdrenka M., Aktywni czy bezradni wobec własnej przyszłości, Wydawnictwo Naukowe UMK, Torun 2004.

Leder A., Prześniona rewolucja. Ćwiczenia z logiki historycznej, Wydawnictwa Krytyki Politycznej, Warszawa 2013.

Liessmann K.P., Theorie dr Unbildung. Irrtumer der Wissensgesellsshaft, Paul Zsolnay Verlag, Vien 2006 (patrz szerokie omówienie w artykule L. Żylińskiego, O iluzjach edukacji, Przegląd Polityczny, 2007, 82).

McLaren P., Życie w szkotach. Wprowadzenie do pedagogiki krytycznej, Wydawnictwo Naukowe DSW, Wrocław 2015.

Melosik Z., Wspótczesne amerykańskie spory edukacyjne. Między socjologia edukacji a pedagogika postmodernistyczna, Wydawnictwo Naukowe UAM, Poznań 1994.

Melosik Z., Uniwersytet i społeczeństwo. Dyskursy wolności, wiedzy i władzy, Oficyna Wydawnicza Impuls, Kraków 2000.

Mikiewicz P., Społeczne światy szkót średnich. Od trajektorii marginesu do trajektorii sukcesu, Wydawnictwo Naukowe DSWE, Wrocław 2005.

Molier, Mieszczanin szlachcicem, przekł. T. Boy-Żeleński, Ossolineum, Lwów 1927.

Nalaskowski A., Nauczyciele z prowincji u progu reformy edukacji, Wydawnictwo Adam Marszałek, Torun 1997.

Nalaskowski A., Edukacja, która nie chce przeminać, Oficyna Wydawnicza Impuls, Kraków 1999.

Nowak L., O składowych procesu wychowania w świetle nieewangelicznego modelu człowieka, Socjologia Wychowania AUNC, 1993, 10.

Proctor R.N., A missing term to describe the cultural production of ignorance (and its study), [w:] Agnotology. The making and unmaking of ignorance, red. R.N. Proctor, L. Schiebinger, Stanford University, Stanford 2008.

Potulicka E., Rutkowiak J., Neoliberalne uwiktania edukacji, Oficyna Wydawnicza Impuls, Kraków 2010. 
Raport o stanie oświaty w PRL, Komitet Ekspertów dla Opracowania Raportu o stanie oświaty w PRL, PWN, Warszawa maj 1973, przewodniczący Jan Szczepański.

Raport Polska 2050, red. M. Kleiber i in., Polska Akademia Nauk - Komitet Prognoz „Polska 2000 Plus", PAN, Warszawa 2011.

Reykowski J., Różnice mentalności jako źródła ideologicznych konfliktów, Nauka, 2013, 3.

Rodziewicz E., Poziom kompetencji i wyborów kulturowych młodzieży z marginesu oświatowego, Socjologia Wychowania AUNC, 1986, 6.

Sadownik A., Na rozstajnych drogach. Studium etnopedagogiczne kontrastowych karier szkolnych młodzieży, Wydawnictwo Naukowe DSW, Wrocław 2011.

Subsumpcje edukacji, red. M. Chutorański, J. Moroz, O. Szwabowski, Wydawnictwo Naukowe KATEDRA, Gdańsk 2017.

Szafraniec K., Anomia - przesilenie tożsamości. Jednostka i społeczeństwo wobec zmiany, Wydawnictwo Naukowe UMK, Torun 1986.

Szkudlarek T., On the politics of educational theory, Routledge, New York-London 2017.

Śliwerski B., Problemy wspótczesnej edukacji. Dekonstrukcja polityki oświatowej III RP, Wydawnictwa Akademickie i Profesjonalne, Warszawa 2009.

Titma M.H., Wybor professii kak socjalnaja problema, Izdatielstwo „Mysl”, Moskwa 1975.

Wasiliewa E.K., Siemja i jejo funkcji. Demografo-statisticzeskij analiz, "Statistika", Moskwa 1975.

Wilber K., Trump and post-truth. An evolutionary self-correction, Seria "Integral Life", e-book, 2017. OP-Ed.

Witkowski L., Edukacja przez pryzmat teorii społecznej J. Habermasa, Socjologia Wychowania AUNC, 1984, 5.

Witkowski L., Tożsamość i zmiana. Wstęp do epistemologicznej analizy kontekstów edukacyjnych, Wydawnictwo Naukowe UMK, Torun 1988.

Witkowski L., Rozwój i tożsamość w cyklu życia. Studium koncepcji E. H. Ericsona, Wydawnictwo Naukowe UMK, Toruń 1989. 